\title{
The Socially Accountable Professor in Higher Education
}

\author{
Brian M. Ross ${ }^{1}$ \\ ${ }^{1}$ Northern Ontario School of Medicine, and Faculty of Education, Lakehead University, Thunder Bay, Ontario, \\ Canada \\ Correspondence: Brian M. Ross, Division of Medical Sciences, Northern Ontario School of Medicine, Lakehead \\ University, 955 Oliver Road, Thunder Bay, Ontario, P7AE8 Canada. Tel: 1-807-766-7394. E-mail: \\ bross@nosm.ca
}

Received: June 19, 2018

Accepted: July 10, $2018 \quad$ Online Published: July 20, 2018

doi:10.5539/jel.v7n5p181

URL: https://doi.org/10.5539/jel.v7n5p181

\begin{abstract}
Social accountability has become an important philosophy driving the development of health professional education which is responsive to the needs of the wider community. Although the inention to be socially accountable is usually expressed at the level of the institution, the institution's educational mission is carried out largely by its faculty. Moreover, while the actions of a socially accountable educational institution have been well described, what individual faculty should do to support such a mission is much less clear. This paper summarises the literature surround community-responsive education and makes recommendations regarding how faculty should act to support social accountability including a commitment to community-service as a professional value, seeing oneself as part of the wider community rather than distinct from it, being actively community engaged, measuring success by means of community impact, and being involved in the internal governance and leadership of the institution.
\end{abstract}

Keywords: social accountability, medicine, faculty agency

\section{Introduction}

\subsection{Social Accountability as an Institutional Aim}

A socially accountable healthcare system is one which works to meet the needs of the society it serves, and doing so is a key objective of health care providers, healthcare institutions, and governments (World Health Organisation, 1978; Boelen \& Heck, 1995). Medical schools play an important part in realising the goals of social accountability in that they provide the means to modify the healthcare workforce to align with societal needs (Health Canada, 2001). Specifically, socially accountable medical education has been defined as the obligation of medical schools to "direct their education, research and service activities towards addressing the priority health concerns of the community, region, and/or nation they have a mandate to serve" with these priority health concerns being "identified jointly by governments, health care organizations, health professionals and the public" (Boelen \& Heck, 1995). For example, the Northern Ontario School of Medicine (the author's institution) was founded with an explicit social accountability mandate, this being to train physicians who can and will work in the north of the Canadian province of Ontario, a huge and mostly rural and sparsely populated region that has poorer health outcomes and lower life expectancy compared to the more populace urbanised south of the province (Buske et al., 1999; Statistics Canada, 1999; Strasser, 2003). Much has been written about how medical schools should go about achieving social accountability, such as by training physicians to deliver healthcare to marginalised or underserved populations, or engaging in various forms of health advocacy (Boelen et al., 2012; Boelen \& Woodward, 2009; Boelen et al., 2012; Ross et al., 2014). Such institutional measures are well established in many medical schools and may well become the norm for medical education in the future (Boelen \& Woollard, 2009).

\subsection{Translating Social Accountability to Faculty Action}

What, however, of the individual faulty member who, by virtue of the autonomy brought by the combination of tenure and academic freedom, as well as their training and socialisation into academia, is free to engage in teaching and research which may be indifferent or even run counter to the institutional mission? A call for University faculty to align their academic work to serving community need has a long history (Boyer, 1990; Lynton, 1995; Harkavy, 1997). Most recently Ellaway (1997) has urged medical school faculty to act with moral 
agency for the good of their community, as opposed to being purely curiosity-driven scholars, which for socially accountable programs provides the foundational underpinning relating the institutional mission to that of individual action. This can be viewed as moving from a mode of academic work in which faculty create and disseminate knowledge, to an approach in which knowledge is co-created with the wider community (Roper \& Hirth, 2005). Many faculty will, however, have been trained in environments which do not gauge the success of academic work in terms of an alignment with community need, or whether it is done in partnership with community members. It may not be straightforward for many traditionally trained faculty to work, or even conceive, of their scholarly work in such terms. Moreover, even faculty members with a desire to act in a socially accountable manner may not know how to go about this. In this paper I will review the literature regarding community engaged-scholarship to draw some conclusions regarding how individual faculty should go about supporting the mission of a socially accountable institution.

\section{The Socially Accountable Professor}

\subsection{Commitment to Community-Service}

The initial step may seem obvious, but it needs to be stated that conducting one's academic work in a socially accountable manner requires an active choice to do so. There is no such thing, in my view, as passive or vicarious social accountability which occurs merely by virtue of where one happens to be working; rather it has to be a willful part of one's professional practice, that is a commitment to carry out high quality academic work for the good of society (Douglas et al., 2012; Puschel et al., 2014) As such social accountability can be viewed both as an institutional mission but also as a personal value, one that guides an individual academic life and which forms part of a faculty member's professional identity. Such a value is closely linked to a commitment to social justice, societal well-being, and the democratic ideal of equity, values which are seen as key for the successful engagement of academia with the wider community (Shackford-Bradley, 2013; Fitzgerald et al., 2016; Beaulieu et al., 2018). Beyond this, however, what should a faculty member actually do? I will argue that the literature regarding academic work conducted with and for the served community suggests several approaches, all of which all involve embracing the idea of academic work as community-service, these being (i) broadening one's academic community, (ii) active community engagement, (iii) being focussed on community-impact as a measure of success, and (iv) a commitment to institutional involvement.

\subsection{Broaden One's Academic Community}

Social accountability can be viewed as an outward looking philosophy which invites faculty to engage with those outside of the institution so that a community's health, or any other priority or need, can be both known and acted on. This is contrast to the rather inward-looking stance of the traditional university and the varied academic disciplines which are largely guided from within, and which tend to promote a faculty-centric approach to academic work (Boyer, 1990; Lynton, 1995). From an epistemological standpoint, socially accountable academic work has its foundation in the constructionist view of knowledge creation in that it is contextualized, changing, and grows from the collaboration between the institution, it's faculty and students, and the wider community (Hood 2002; Weert \& Sandman, 2008). In essence, socially accountable scholarship requires a lessening of the boundaries between an institution's faculty and the served community, something that social accountability shares with other forms of community-engaged scholarship (Weerts \& Sandman, 2008). This means that traditional areas of 'faculty work' such as curriculum development, teaching, and research must, in a significant and meaningful manner, involve the wider community including an ability to evaluate whether their priorities are being met (Boelen \& Woolard, 2009). This can be a rather threatening idea for faculty used to being evaluated by disciplinary peers situated within the academy, and for whom social accountability might be perceived as a transfer of power away from the professor. Looked at in this way social accountability is a 'zero sum' scenario in which for the community to gain power, the faculty member must lose theirs. This is a rather fundamental matter which can lead to disengagement and conflict (DeLugan et al., 2014). It can be resolved, however, by changing one's perspective from 'them' and 'us', to 'we'. Social accountability therefore requires a blurring of the boundaries of professional life, with the institution and its faculty being of the community, not separate from it. This has been described as the integration of academic work with citizenship to become a 'citizen-scholar' (Bridger \& Alter, 2006; Hartelius et al., 2010; Shackford-Bradley, 2013). This may not be an easy transition to make, particularly for those trained in a traditional academic environment, but it an indispensable epistemological stance for the socially accountable professor to take.

\subsection{Be Actively Community-Engaged}

Social accountability requires faculty to engage and communicate with the wider community, not just to allow the discovery of what the priority needs of the community are, but to take part in a partnership aimed at 
co-creating educational and research programs by which these needs are to be met (Boelen \& Heck, 1995). Put another way, social accountability is about the democratization of academic work via a process of community engagement (Brown et al., 2003). As academic work is a varied endeavour, this implies that faculty must be personally, rather than vicariously, community-engaged, a matter that is generally left unaddressed in the literature regarding socially accountable medical education. In medicine this may include engaging with patient advocacy groups, health service leadership and administration, community-based physicians, and not-for-profit healthcare-related agencies, in order to gain information about what is needed by the wider community that one's expertise can be used to meet. Over and above simple informational exchange, such dialogue is a necessary first step for the the arguably more difficult task of developing actual community partnerships. The interaction between the community and academic institutions has been well studied, however, and can be used to guide faculty in how to best go about engaging the wider community. In terms of barriers, the perceived or actual power differences between university faculty and community members has been identified as the key impediment to community-engaged academic work (Weerts, 2008). This manifests itself in the nature of the relationship faculty have with community members which varies in terms of both inclusion, that is who is involved, and the degree of influence afforded to community members (Arnstein, 1969; Nolte \& Voget-Kleschin, 2014). With respect to the latter this can range from being relatively disempowered and merely being informed about what is occurring, through being involved in a consultation process where community views are heard but not necessarily acted on, to a partnership model in which all parties have a say over what occurs (Weerts, 2008). With this in mind, the partnerships which lie at the heart of social accountability requires that the served community must be involved and empowered in decision making at all stages, including the conception, development, implementation, and evaluation of teaching and research (Weerts, 2007; Boelen \& Woolard, 2009). This is necessary to ensure that the process of engagement empowers the community in a way which meets its needs, rather than exploits the community in terms of the resources it can provide to the institution, or to the faculty member.

While effective community partnerships most certainly require action at the institutional level (Brown et al., 2003; Boelen et al., 2012), the individual faculty member also can organize their work in a manner which support the process of co-creation. For example, the use of of research methodologies such as participatory action research (Cornwall \& Jewkes, 1995), in which research is with and for the benefit of the participants, should be considered. Another approach is that of integrated scholarship where teaching, research and service can be done in a community-engaged and supportive manner, and where teaching modalities such as service learning lead to the meeting of community needs which then form the basis of future research, repeating in a virtuous cycle (Calleson et al., 2005; Hofmeyer et al., 2007). Indeed, incorporating service learning into academic work is a commonly used route towards the goal of having a community-engaged and socially accountable academic life (Dharamsi et al., 2010; Meili et al., 2011; Woolard \& Boelen, 2012). Both participatory research and integrated scholarship offer the opportunity to develop sustained personal relationships and build trust with members of the wider community, elements that have been argued to be essential to the process of community engagement and establishing partnerships (Hutchinson \& Huberman, 1994; Maurrasse, 2001). Successful community engagement has also been argued to require the academic partner to be (i) accessible, such that the wider community can initiate partnerships, query progress etc, (ii) be available in terms of timeliness, and (iii) be adaptable and able to change in step with the needs of the community (Hutchinson \& Huberman, 1994). Although the ideas of adaptability, accessibility, and availability were described by Hutchinson \& Huberman (1994) in terms of institutional attributes, their application to an individual's academic life may be useful as both guiding principles, and as an evaluative framework which allows the would-be socially accountable professor to reflect on the adequacy of their own academic practice.

\subsection{Gauge Professional Success in Terms of Community Impact}

As I have stated, community-engagement in any form may be a new approach for many faculty who were trained in a traditional academic environment, a career path which does not usually require any sort of community involvement (O'Meara \& Jaeger, 2007). Indeed, it is those who are found worthy by the standards of the faculty member's own discipline who are rewarded with career progression, with the opinions of those who would ordinarily be considered 'lay' members of the community being of little import (Golde \& Dore, 2001; Austin, 2006). Moreover, some forms of community-engaged academic work are not viewed not as scholarship at all, but as a form of service (Calleson et al., 2005). Unfortunately service is generally not as valued or rewarded as the other two components of academic work, teaching and, in particular, research (Lynton, 1995). To make matters worse, service in traditional academic environments is normally limited to either peer-review and other activities associated with the faculty member's academic discipline, or to various forms of institutional 
governance, with community-service being a minor and unusual component (Checkoway, 2013). For example, using one's expertise to assist community groups achieve their goals is viewed as an important and impactful part of socially accountable academic work, yet in some academic environments such community-service is actually stigmatized (Jaeger \& Thornton, 2005; Weert \& Sandman, 2008; Douglas, 2012). Such negative views regarding service can represent a substantial barrier to community-engagement as it can result in faculty avoiding such activities, particularly those in the early stages of their career when the approval or disapproval of peers is critical to their progressions. Since, such a barrier can be viewed as a lack of reciprocity, with the community gaining more than the faculty member from such a relationship, it is notable that reciprocity is viewed as a key feature of successful engagement (Beaulieu et al., 2018) but is somewhat at odds with the literature regarding social accountability which values not recipricocity but altruism (Boelen \& Woolard, 2009; McCrea \& Murdoch-Eaton, 2014). The answer may be to prioritze community-impact as a key measure of academic success, equal to or even superior to the number of papers published or amount of research monies gained (Barge \& Shockley-Zalabak, 2008; O'Meara \& Jaegar, 2006). This is not consistent with most institutional appointment, tenure and promotion policies, many of which do not even consider community-impact, and which utilise external peer reviewers drawn from non-socially accountable universities (Barge \& Shockley-Zalabak, 2008; Ross, 2014; Beaulieu et al., 2018). As such the institution also has a large role to play by mazimising reciprocity in community partnerships and ensuring that a faculty member is rewarded rather than punished for their efforts (Calleson et al., 2005). Without such institutional consideration it will remain something of a balancing act for faculty seeking to act in a socially accountable manner.

\subsection{Be Involved in the Institutional Structures that Promote Socially Accountability}

A socially accountable institution requires that the institution be organised in a manner which allows its educational and research programs to be planned and implemented in a way which facilitates the school's mission (Boelen \& Woolard, 2009). Being involved in such structures is therefore an important mechanism by which a faculty member may not only contribute to and become informed about the overall mission, but also to ensure that the governance and management processes of the school, which are in principle aligned with the goals of social accountability achieve what they are meant to do. Furthermore, committee work encourages faculty members to act in a manner which considers the views and needs of all participants including that of community partners if they are represented within the governance structures. Indeed, it encourages faculty to collaborate and reduces the tendency of faculty to act in an idiosyncratic and self-serving manner disconnected from the institutional aims and, more importantly, community needs (Briggs, 2007, Brauer \& Ferguson, 2015). Doing so invariably involves sitting on committees, and the taking on of academic governance and leadership roles. Again, such work is generally viewed as service, rather than teaching or scholarship, and is actively avoided by many faculty due to it having a reputation as time consuming and unrewarded (Terpstra \& Honoree, 2009). The means to change such views are in some part within the hands of faculty members since the reward structures which must support social accountability are embedded in the contracts and collective agreements that faculty in Canada and elsewhere negotiate with their institution (Ross, 2014). Ensuring that community-engaged scholarship, for example, is encouraged rather than hindered needs faculty who are committeed to social accountability to be active in the unions and associations that represent them thereby allowing them the opportunity to influence how academic work is performed and valued within their own institution.

\section{Concluding Remarks}

In summary, social accountability at the level of the individual faculty member comprises having community-service as a core component of one's professional life and being committed to being impactful with respect to community needs. It also involves acting in a manner which prioritise service to one's colleagues, the institution, and the wider community. To achive this while the institution must provide extrinsic motivation in the form of appropriate reward structures, the prime mover for the socially accountable professor must mainly come from within.

\section{References}

Arnstein, S. R. (1969). A ladder of citizen participation. Journal of the American Institute of Planners, 35, 216-224. https://doi.org/10.1080/01944366908977225

Austin, A. E., \& McDaniels, M. (2006). Using doctoral education to prepare faculty to work within Boyer's four domains of scholarship. In J. M. Braxton (Ed.), Analyzing faculty work and rewards: Using Boyer's four domains of scholarship. New directions for institutional research, no. 129 (pp. 51-66). San Francisco, California: Jossey-Bass. https://doi.org/10.1002/ir.171

Barge, J. K., \& Shockley-Zalabak, P. (2008). Engaged scholarship and the creation of useful organizational 
knowledge. Journal of Applied Communication Research, 36, 251-265. https://doi.org/10.1080/00909880802172277

Beaulieu, M., Breton, M., \& Brousselle, A. (2018). Conceptualizing 20 years of engaged scholarship: A scoping review. PloS One, 13, e0193201. https://doi.org/10.1371/journal.pone.0193201

Boelen, C., \& Heck, J. E. (1995). Defining and measuring the social accountability of medical schools. Geneva: Division of Development of Human Resources for Health, World Health Organization.

Boelen, C., \& Woollard, B. (2009). Social accountability and accreditation: a new frontier for educational institutions. Medical Education, 43, 887-894. https://doi.org/10.1111/j.1365-2923.2009.03413.x

Boelen, C., Dharamsi, S., \& Gibbs, T. (2012). The social accountability of medical schools and its indicators. Education for Health, 25, 180. https://doi.org/10.4103/1357-6283.109785

Boyer, E. L. (1990). Scholarship reconsidered: priorities of the professoriate. Princeton, NJ: Carnegie Foundation.

Brauer, D. G., \& Ferguson, K. J. (2015). The integrated curriculum in medical education: AMEE Guide No. 96. Medical teacher, 37, 312-322. https://doi.org/10.3109/0142159X.2014.970998

Bridger, J. C., \& Alter, T. R. (2007). The engaged university, community development, and public scholarship. Journal of Higher Education Outreach and Engagement, 11, 163-178.

Briggs, C. L. (2007). Curriculum collaboration: A key to continuous program renewal. Journal of Higher Education, 78, 676-711. https://doi.org/10.1353/jhe.2007.0036

Brown, L. D., Bammer, G., Batliwawa, S., \& Kunreuther, F. (2003). Framing practice-research engagement for democratizing knowledge. Action Research, 1, 81-102. https://doi.org/10.1177/14767503030011006

Buske, L. M., Yager, S. N., Adams, O. B., Marcus, L., \& Lefebvre, F. A. (1999). Rural community development tools from the medical perspective: A national framework of rurality and projections for physician workforce supply in rural and remote areas of Canada. Report to Health Canada. Shawville, Quebec, Canada: Society of Rural Physicians of Canada.

Calleson, D. C., Jordan, C., \& Seifer, S. D. (2005). Community-engaged scholarship: Is faculty work in communities a true academic enterprise? Academic Medicine, 80, $317-321$. https://doi.org/10.1097/00001888-200504000-00002

Checkoway, B. (2013). Strengthening the scholarship of engagement. Journal of Higher Education Outreach and Engagement, 17, 7-22.

Cornwall, A., \& Jewkes, R. (1995). What is participatory research? Social Science \& Medicine, 41, $1667-1676$. https://doi.org/10.1016/0277-9536(95)00127-S

DeLugan, R. M., Roussos, S., \& Skram, G. (2014). Linking academic and community guidelines for community-engaged scholarship. Journal of Higher Education Outreach and Engagement, 18, 155-168.

Dharamsi, S., Espinoza, N., Cramer, C., Amin, M., Bainbridge, L., \& Poole, G. (2010). Nurturing social responsibility through community service-learning: Lessons learned from a pilot project. Medical Teacher, 32, 905-911. https://doi.org/10.3109/01421590903434169

Douglas, S. (2012). Advancing the scholarship of engagement in higher education: a strategic review, 1996-2006. Review of Sociology, 43, 27-39.

Ellaway, R. H. (2017). Moral agency and the medical education researcher. Medical Education, 51, 3-5. https://doi.org/10.1111/medu.12924

Fitzgerald, H. E., Bruns, K., Sonka, S. T., Furco, A., \& Swanson, L. (2016). The centrality of engagement in higher education. Journal of Higher Education Outreach and Engagement, 20, 223-244.

Golde, C. M., \& Dore, T. M. (2001). At cross purposes: What the experiences of today's doctoral students reveal about doctoral education. Philadelphia, PA: Pew Charitable Trust.

Harkavy, I. (1997). Organizational innovation and the creation of the American university: The University of Pennsylvania's Center for Community Partnerships as a developing case study. In R. M. Lerner \& L. A. K. Simon (Eds.), University-Community Collaborations for the Twenty-First Century: Outreach Scholarship for Youth and Families (pp. 275-287). New York: Garland Publisher.

Hartelius, E. J., \& Cherwitz, R. A. (2010). The Dorothy Doctrine of engaged scholarship: The rhetorical 
discipline "had it all along". Quarterly Journal of Speech, 96, 436-442. https://doi.org/10.1080/00335630.2010.521180

Health Canada. (2001). Social accountability. A vision for Canadian medical schools. Health Canada, Ottawa, Canada.

Hofmeyer, A., Newton, M., \& Scott, C. (2007). Valuing the scholarship of integration and the scholarship of application in the academy for health sciences scholars: recommended methods. Health Research Policy and Systems, 5, 5. https://doi.org/10.1186/1478-4505-5-5

Hood, P. (2002). Perspectives on knowledge utilization in education. San Francisco: WestEd.

Hutchinson, J. R., \& Huberman, M. (1994). Knowledge dissemination and use in science and mathematics education: A literature review. Journal of Science Education and Technology, 3, 27-47. https://doi.org/10.1007/BF01575814

Jaeger, A. J., \& Thornton, C. H. (2005). Moving toward the market and away from public service? Effects of resource dependency and academic capitalism. Journal of Higher Education Outreach and Engagement, 10, 53-67.

Lynton, E. A. (1995). Professional service: why it is needed, and what it is, and how it can be documented and evaluated. Washington, DC: American Association for Higher Education.

Maurrasse, D. J. (2001). Beyond the campus: How colleges and universities form partnerships with their communities. New York: Routledge.

McCrea, M. L., \& Murdoch-Eaton, D. (2014). How do undergraduate medical students perceive social accountability?. Medical teacher, 36, 867-875. https://doi.org/10.3109/0142159X.2014.916784

Meili, R., Fuller, D., \& Lydiate, J. (2011). Teaching social accountability by making the links: qualitative evaluation of student experiences in a service-learning project. Medical Teacher, 33, 659-666. https://doi.org/10.3109/0142159X.2010.530308

Nolte, K., \& Voget-Kleschin, L. (2014). Consultation in large-scale land acquisitions: An evaluation of three cases in Mali. World Development, 64, 654-668. https://doi.org/10.1016/j.worlddev.2014.06.028

O'Meara, K., \& Jaeger, A. J. (2007). Preparing future faculty for community engagement: Barriers, facilitators, models, and recommendations. Journal of Higher Education Outreach and Engagement, 11, 3-26.

Puschel, K., Rojas, P., Erazo, A., Thompson, B., Lopez, J., \& Barros, J. (2014). Social accountability of medical schools and academic primary care training in Latin America: principles but not practice. Family Practice, 31, 399-408. https://doi.org/10.1093/fampra/cmu010

Roper, C. D., \& Hirth, M. A. (2005). Ahistory of change in the third mission of higher education: the evolution of one-way service to interactive engagement. Journal of Higher Education Outreach and Engagement, 10, $3-21$.

Ross, B. M. (2014). Sustainability and social accountability. In 2014 Sustainability Across the Curriculum Workshop Faculty Narratives. Thunder Bay, Ontario: Centre for Place and Sustainabilty Studies, Lakehead University.

Ross, S. J., Preston, R., Lindemann, I. C., Matte, M. C., Samson, R., Tandinco, F. D., Larkins, S. L., Palsdottir, B., \& Neusy, A. J. (2014). The training for health equity network evaluation framework: a pilot study at five health professional schools. Education for Health, 27, 116-126. https://doi.org/10.4103/1357-6283.143727

Shackford-Bradley, J. (2013). Human rights in everyday life: Partnering human rights and service-learning/engaged scholarship in local communities. Partnerships: A Journal of Service-Learning and Civic Engagement, 4, 137-163.

Statistics Canada. (1999). Life expectancy. Health reports, 11, 9-24.

Strasser, R. (2003). Rural health around the world: challenges and solutions. Family Practice, 20, $457-463$. https://doi.org/10.1093/fampra/cmg422

Terpstra, D. E., \& Honoree, A. L. (2009). The effects of different teaching, research, and service emphases on individual and organizational outcomes in higher education institutions. Journal of Education for Business, 84, 169-176. https://doi.org/10.3200/JOEB.84.3.169-176

Weerts, D. J. (2007). Toward an engagement model of institutional advancement at public colleges and 
universities. International Journal of Educational Advancement, 7, 79-103. https://doi.org/10.1057/palgrave.ijea.2150055

Weerts, D. J., \& Sandman, L. R. (2008). Building a two-way street: challenges and opportunities for community engagement at research universities. Review of Higher Education, 32, 73-106. https://doi.org/10.1353/rhe.0.0027

Woollard, B., \& Boelen, C. (2012). Seeking impact of medical schools on health: meeting the challenges of social accountability. Medical Education, 46, 21-27. https://doi.org/10.1111/j.1365-2923.2011.04081.x

World Health Organization. (1978). The declaration of Alma-Ata: The international conference of primary healthcare. Alma-Ata, USSR. Geneva: World Health Organisation.

\section{Copyrights}

Copyright for this article is retained by the author, with first publication rights granted to the journal.

This is an open-access article distributed under the terms and conditions of the Creative Commons Attribution license (http://creativecommons.org/licenses/by/4.0/). 